\title{
Chromium (VI) Biosorption from Aqueous Solutions by Free and Immobilized Biomass of Oscillatoria sp. H1 Isolated from Freshwater
}

\author{
Hikmet KATIRCIOĞLU, ${ }^{1) *}$ Belma ASLIM ${ }^{2)}$ and Adalet TUNÇELỉ) \\ 1) Department of Biology Education, Faculty of Education, Gazi University, 06500, Ankara, TURKEY. E-mail: hturk@gazi.edu.tr \\ 2) Department of Biology, Faculty of Arts and Science, Gazi University, 06500, Ankara, TURKEY. E-mail: baslim@gazi.edu.tr \\ 3) Department of Chemistry, Faculty of Arts and Science, Gazi University, 06500, Ankara, TURKEY. E-mail: adalet@gazi.edu.tr
}

(Received on February 10, 2010; accepted on March 9, 2012)

\begin{abstract}
The Oscillatoria sp. H1 (Cyanobacteria) isolated from Mogan Lake was researched for the removal of chromium (VI) ions from aqueous solutions and were used free (dry biomass), immobilized (in Ca-alginate) live and immobilized heat-inactivated biomass as biosorbents. Particularly, the effects of physico-chemical parameters like $\mathrm{pH}$, the temperature change, initial concentration, biosorption time and biosorbent dosages on the biosorption of $\mathrm{Cr}(\mathrm{VI})$ ions were investigated. The biosorption of $\mathrm{Cr}(\mathrm{VI})$ ions for all biosorbents was determined as a highest value at $\mathrm{pH}$ 6.0. The temperatures which changed between 20 and $40^{\circ} \mathrm{C}$ did not affect the biosorption capacity.

The biosorption of $\mathrm{Cr}(\mathrm{VI})$ ions on both free (dry) and immobilized (live and heat-inactivated) Oscillatoria $\mathrm{sp}$. $\mathrm{H} 1$ biomass $(\mathrm{mg} / \mathrm{g}$ ) increased as the initial concentration of $\mathrm{Cr}(\mathrm{VI})$ ions was increased in the medium. Biosorption equilibrium was established in about $60 \mathrm{~min}$. The retention of $\mathrm{Cr}(\mathrm{VI})$ increased with increasing the amount of the adsorbent up to $0.04 \mathrm{~g}$ and 30 bead. The results show that immobilized inactive cells $(13.83 \mathrm{mg} / \mathrm{g})$ and dry biomass $(15.81 \mathrm{mg} / \mathrm{g})$ had less biosorption capacity than that of the immobilized live form $(20.82 \mathrm{mg} / \mathrm{g})$. The Langmuir and Freundlich isotherm models were used to fit the equilibrium biosorption data. The biosorbent systems could be regenerated by washing with a solution of $10 \mathrm{mM} \mathrm{HCl}$. The percent desorption achieved was as high as $98 \%$. The biosorbents were reused in three biosorptiondesorption cycles without significant loss of their initial biosorption capacity. The results indicated that the immobilized live Oscillatoria sp. $\mathrm{H} 1$ could be suitable for development of an efficient biosorbent for the removal of chromium (VI) from wastewater from some industrial processes and other ones.
\end{abstract}

KEY WORDS: $\mathrm{Cr}(\mathrm{VI})$; biosorption; microalgae; Ca-alginate; Oscillatoria sp.

\section{Introduction}

Widespread contamination of freshwater with various toxic and non-biodegradable heavy metals poses several health problems and consequently need to be decontaminated to standard permissible levels. The chromium $(\mathrm{Cr})$ in the effluents of industries like leather tanning, electroplating, textile dyeing and metal finishing exists in hexavalent and trivalent forms and the former is more toxic and may cause cancer in the digestive tract and lungs of human beings. ${ }^{1)}$ Paint manufacturing, ink formulating and dye house wastewaters contain chromium concentrations ranging from 0.4 to $7.5 \mathrm{mg} / \mathrm{L}, 150 \mathrm{mg} / \mathrm{L}$ and $300 \mathrm{mg} / \mathrm{L}$, respectively. According to the US Environmental Protection Agency, the acceptable amount for heavy metal ions is usually less than $1.0 \mathrm{mg} / \mathrm{L} .^{2)}$ Moreover, in environment air, chromium particulates play a role in the oxidation of sulfur dioxide and the formation of acidic aerosols involved in global acid rain. ${ }^{3)}$

Conventional techniques for removing dissolved heavy metals include precipitation, adsorption and ion-exchange. The conventional methods for removing metals from waste- waters are generally expensive and have many limitations. For iron and steel manufacturing, wastewater treatment systems typically include sedimentation to remove suspended solids, physical or chemical treatment such as $\mathrm{pH}$ adjustment to precipitate heavy metals, and filtration. In recent years, alternative methods for metal removal and recovery based on biological materials have been considered. Bioremoval involves a combination of active and passive transport mechanisms. The first stage, usually referred to as passive uptake, is an initial rapid and reversible accumulation step. This kind of adsorption is also termed biosorption. ${ }^{2)}$ Biosorption and/or bioaccumulation has emerged as a cost-effective and efficient alternative method. Biosorption utilizes the ability of biological materials to accumulate heavy metals from waste streams by either metabolically mediated or purely physico-chemical pathways of uptake. A wide range of non-living biomass like bark, lignin, peanut, hulls, as well as living biomass like fungi, bacteria, ${ }^{4)}$ yeast, moss, aquatic plants ${ }^{5)}$ and algae has been used as biosorbents. $^{6-11)}$

Algal biosorbents for metal removal from aqueous solu- 
tion are in use for quite some time and for this purpose both live and dead mass of algae have been tried and reported as biosorbents. ${ }^{11,12)}$ Therefore, there are some reports on the use of immobilized algae as biosorbents. ${ }^{1)}$

Cyanobacteria have a great potential for use as effective biosorbents, because they are easy to grow with simple nutrient requirements and unlike other microbial systems, they generally do not produce toxins. Further, cyanobacteria produce extracellular polysaccharides that have a tendency of binding metals. There are some reports on biosorption of heavy metals like copper, nickel, zinc and chromium by certain species of cyanobacteria and microalgae, ${ }^{1)}$ but there are few studies on biosorption of metals by Oscillatoria sp. that can be conveniently used for biosorption studies. Also, as a biosorbent, this strain is both cost-effective and non-toxic. ${ }^{7)}$

The aim of this study was to determine the ability as a biosorbent of Oscillatoria sp. H1 for the removal of chromium (VI) from aqueous solutions and compare the adsorption behavior of different biosorbent forms: dry biomass, immobilized live and heat-inactivated Oscillatoria sp. H1.

\section{Material and Methods}

\subsection{Microorganism and Media}

The test organism Oscillatoria sp. H1 was isolated from freshwater samples (from Mogan Lake in Ankara, Turkey) and pure culture was grown on BG-11 medium $\left[\mathrm{NaNO}_{3}, 15\right.$; $\mathrm{K}_{2} \mathrm{HPO}_{4}, 0.4 ; \mathrm{MgSO}_{4} .7 \mathrm{H}_{2} \mathrm{O}, 0.75 ; \mathrm{CaCl}_{2} .2 \mathrm{H}_{2} \mathrm{O}, 0.36$; citric acid, 0.06; iron(III) ammonium citrate, 0.06; $\mathrm{Na}_{2}$-EDTA, $0.01 ; \mathrm{Na}_{2} \mathrm{CO}_{3}, 0.2 \mathrm{~g} / \mathrm{L}, 1 \mathrm{~mL}$; trace elements solution, $\left(\mathrm{H}_{3} \mathrm{BO}_{3}, \quad 61 ; \quad \mathrm{MnSO}_{4} \cdot \mathrm{H}_{2} \mathrm{O}, \quad 169 ; \quad \mathrm{ZnSO}_{4} .7 \mathrm{H}_{2} \mathrm{O}, \quad 287\right.$; $\left.\mathrm{CuSO}_{4} .5 \mathrm{H}_{2} \mathrm{O}, 2.5 ;\left(\mathrm{NH}_{4}\right)_{6} \mathrm{Mo}_{7} \mathrm{O}_{24} .4 \mathrm{H}_{2} \mathrm{O}, 12.5 \mathrm{mg} / \mathrm{L}\right) \mathrm{pH}$ : 6.8] which is commonly used for growing blue-green algae in flasks. This medium contains only trace amounts of metal ions and allows rich growth. This strain was determined according to Bone et al. ${ }^{14)}$ and pure culture of the cyanobacterium was obtained by using standard isolation and culturing techniques. ${ }^{13)}$

The algal cultures in sterile shake flasks containing $100 \mathrm{ml}$ BG 11 were maintained at a light intensity of 3000 lux using cool fluorescent tubes at $25^{\circ} \mathrm{C}$ in an incubator (Minitron) suitable for photosynthesis. Fifteen-day-old algal cultures were harvested and the algal biomass was washed with distilled water and oven dried at $100^{\circ} \mathrm{C}$ for $2 \mathrm{~h}$ before use.

\subsection{Immobilization of Oscillatoria sp. H1}

The Oscillatoria sp. $\mathrm{H} 1$ was immobilized on Ca-alginate beads via entrapment by the method given by $\mathrm{Chen}^{15)}$ and Ergene et al. ${ }^{7)}$ Ca-alginate (2.0 g, from Macrosytia pyrifera, high viscosity, Sigma Chem., Co., U.S.A.) was dissolved in $100 \mathrm{~mL}$ of sterile distilled water and mixed with the algal biomass. The mixture was then introduced drop-wise into $0.1 \mathrm{M} \mathrm{CaCl}_{2}$ solution with a burette, while stirring to prevent aggregation of $\mathrm{Ca}$-alginate beads. The beads, approx. $4 \mathrm{~mm}$ in diameter, were cured in the solution for about $1 \mathrm{~h}$, and then washed for three times with $150 \mathrm{~mL}$ of sterile distilled water. The cured beads were stored in $5 \mathrm{mM} \mathrm{CaCl}_{2}$ solution at $4{ }^{\circ} \mathrm{C}$ until use. The dry weight of the prepared biomass was determined after drying the alginate beads overnight in an oven at $50^{\circ} \mathrm{C}$.

\subsection{Reagents}

All chemicals were of analytical reagent grade unless otherwise stated. Double distilled deionized water was used throughout the study. Chromium stock solution (1000 mg/L) was prepared by dissolving a calculated amount of $\mathrm{K}_{2} \mathrm{Cr}_{2} \mathrm{O}_{7}$ (Merck). The working solutions were prepared by diluting the stock solution to appropriate volumes. Britton-Robinson (B-R) buffer solution was prepared by dissolving $2.3 \mathrm{~mL}$ of glacial acetic acid, $2.7 \mathrm{~mL}$ of phosphoric acid and $2.472 \mathrm{~g}$ of boric acid in double distilled water and diluted to $1.0 \mathrm{~L}$. $100 \mathrm{~mL}$ portions of this solution were taken and the desired $\mathrm{pH}$ was adjusted between 2.0 and 8.0 by addition of appropriate amount of $2.0 \mathrm{M} \mathrm{NaOH} .{ }^{16)}$

\subsection{Apparatus}

A Philips PU 9285 model flame atomic absorption spectrometer (AAS) equipped with deuterium lamp background correction, hollow cathode lamp (HCL) and air acetylene burner was used for the determination of chromium. Absorption measurements were performed under the following conditions: wavelengths, $357.9 \mathrm{~nm}$; fuel flow rate, 1.6 $\mathrm{L} \mathrm{min}^{-1}$; HCL lamp current, $9.0 \mathrm{~mA}$; band pass, $0.5 \mathrm{~nm}$ and integration time $4 \mathrm{~s}$. All $\mathrm{pH}$ measurements were performed with a METTLER-TOLEDO model digital $\mathrm{pH}$ meter.

\subsection{Batch Procedure}

Biosorption of $\mathrm{Cr}$ (VI) on dry biomass, immobilized live and heat-inactivated preparations from aqueous solutions was investigated in batch biosorption experiments at $25^{\circ} \mathrm{C}$. The heat-inactivated preparation was obtained by boiling the live algae in water for $10 \mathrm{~min}$. The removal of chromium was tested with synthetic chromium solutions (containing $10 \mathrm{mg}$ of chromium in $100 \mathrm{~mL})$. Dry biomass $(0.04 \mathrm{~g})$ was added to the synthetic solution. The $\mathrm{pH}$ of the solution was adjusted to 6.0 by addition of the Britton-Robinson (B-R) buffer. Then the mixture was agitated using a shaker for 60 $\min$ at $25^{\circ} \mathrm{C}$. Determination of $\mathrm{Cr}$ (VI) ion was performed in liquid phase (supernatant) by flame atomic absorption spectrometry. In order to demonstrate the reusability of the biosorbents, the mixture was filtered through the filter and the retained chromium on the biomass was eluted by $50 \mathrm{~mL}$ of $10 \mathrm{mM} \mathrm{HCl}$ solution.

Each set of experiments was carried out in triplicate, and the mean values were used in the analyses of data. Five measurements for each sample were done to calculate the mean value. Calibrations were performed within a linear calibration range of $\mathrm{Cr}$ (VI), and the calibration curves with correlation coefficients less than 0.990 were repeated. The difference between the initial and remaining metal ion concentrations was assumed to be taken up by the biosorbent.

\subsection{Desorption}

In order to determine the reusability of the biosorbents, consecutive biosorption-desorption cycles were repeated four times using the same cyanobacteria preparations. Desorption of $\mathrm{Cr}(\mathrm{VI})$ was performed by $\mathrm{HCl}(10 \mathrm{mM}, 50 \mathrm{~mL})$. The dry biomass and alginate beads loaded with $\mathrm{Cr}$ (VI) were placed in the desorption medium and were stirred at $100 \mathrm{rpm}$ for $1 \mathrm{~h}$ at $25^{\circ} \mathrm{C}$. After each cycle of adsorptiondesorption, biomass was washed with saline solution. ${ }^{8)}$ The 
final chromium ion concentration in the aqueous phase was determined by using an AAS as described above. Desorption ratio was calculated from the amount of metal ions adsorbed on the dry biomass and immobilized preparations and the final metal ions concentration in the adsorption medium. Desorption ratio was calculated from the following equation: ${ }^{9)}$

Desorption ratio $=$

Amount of $\mathrm{Cr}(\mathrm{VI})$ ions desorbed to the elution medium

Amount of $\mathrm{Cr}(\mathrm{VI})$ ions adsorbed onto biosorbent

\subsection{Selection of Microorganism}

A filamentous cyanobacterium Oscillatoria sp. H1 was used in this study. It is known that the filamentous cyanobacterium has a wide polysaccharide capsule surrounding its entire filament. ${ }^{17)}$ Some cyanobacterial species such as Oscillatoria, Spirulina and Gleocapsa synthesize extracellular organic material such as siderophores with metal complexing properties. In cyanobacteria, Kelly ${ }^{18)}$ demonstrated that heavy metals are accumulated in intracellular storage compartments, called polyphosphate bodies, where metals accumulate, protect algal cells from toxicity. Also, Oscillatoria species (cyanobacteria) are easy to grow with simple nutrient requirements and unlike other microbial systems, they generally do not produce toxins. Therefore, this microorganism was selected for the removal of $\mathrm{Cr}$ (VI).

\subsection{Properties of the Alginate as Support Material}

Alginates were preferred over other materials because of their various advantages such as biodegradability, hydrophilic properties, presence of carboxylic groups and natural origin. Other additional advantages are their low density and mechanical stability that make them highly suitable for many biotechnological applications. ${ }^{6}$ For these properties, in this study, the Ca-alginate beads were used as a support material for the entrapment of Oscillatoria $\mathrm{sp}$.

\section{Results and Discussion}

\subsection{Cr (VI) biosorption}

3.1.1. Effect of $\mathrm{pH}$ and Temperature

Metal ion biosorption onto biosorbents is a $\mathrm{pH}$ dependent process. The metal biosorption depends on the protonation or unprotonation of these functional groups on the surface of the cell wall. The ionic forms of the metal ions in solution and the electrical charge of the algal cell wall components (i.e. functional groups carrying polysaccharides and proteins) depend on the solution $\mathrm{pH} .{ }^{8)}$ Crist et al. ${ }^{19)}$ suggested that isoelectronic point would be found at $\mathrm{pH} 3.0$ for the algal biomass. Above this $\mathrm{pH}$, algal cells would have a net negative charge which would lead to increase in electrostatic attractions between positively charged metal ions and negatively charged binding sites, hence a rapid rise in binding efficiency between $\mathrm{pH} 4.5$ and 5.0.

The effect of $\mathrm{pH}$ on the uptake of chromium ion $(100 \mathrm{mg} / \mathrm{L})$ by all biosorbents was studied in the $\mathrm{pH}$ range from 2.0 to 8.0 adjusting by a Britton-Robinson (B-R) buffer. And quantitative retention of chromium was obtained about at pH 6 (Fig. 1). Within the $\mathrm{pH}$ range of 2.0 to $6.0, \mathrm{Cr}$ (VI) uptake capacities of all biosorbents increased rapidly. Kiran

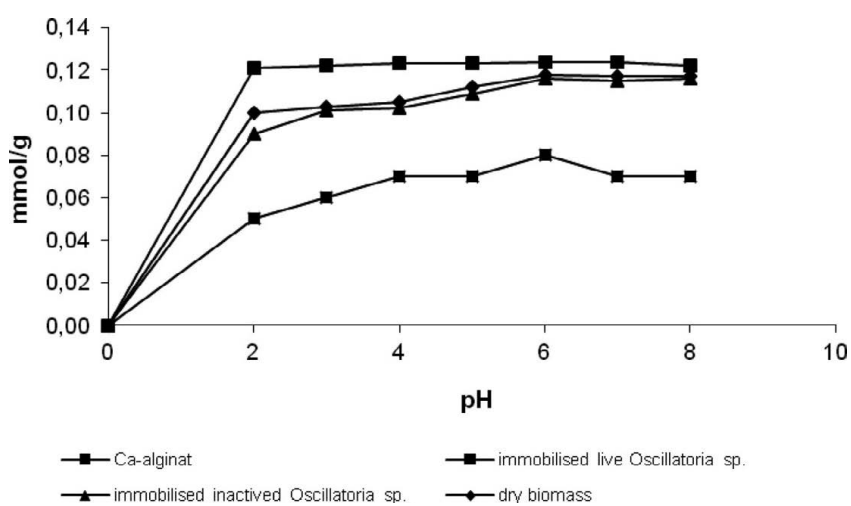

Fig. 1. Effect of initial solution $\mathrm{pH}$ on biosorption of $\mathrm{Cr}$ (VI).

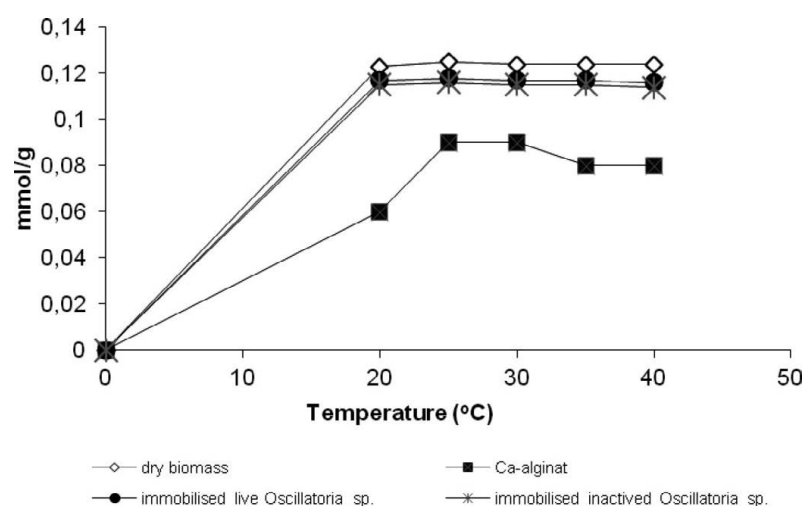

Fig. 2. Effect of temperature $\left({ }^{\circ} \mathrm{C}\right)$ on biosorption of $\mathrm{Cr}(\mathrm{VI})$.

et al. ${ }^{1)}$ reported that the maximum adsorption of $\mathrm{Cr}$ (VI) ions on immobilized Lyngbya putealis biomass was also observed at $\mathrm{pH} 2-3$. Han et al. ${ }^{20)}$ reported that the maximum adsorption of $\mathrm{Cr}$ (VI) ions on the dry biomass of Chlorella miniata was observed at $\mathrm{pH}-3$. However, Congeevaram et $a l .{ }^{21)}$ reported that the maximum removal of $\mathrm{Cr}(\mathrm{VI})$ for bacterial and fungal adsorbents was observed around $\mathrm{pH} 5-6$. Baran et $a .^{22)}$ reported that the $\mathrm{pH}$ between 3 and 7 is widely accepted as optimum for metal uptake for almost all types of sorbents.

The effect of temperature on the metal biosorption experiments was investigated at five different temperatures (from 20 to $40^{\circ} \mathrm{C}$ ) and the maximum biosorpiton capacity was found at $25^{\circ} \mathrm{C}$ (Fig. 2). Several researchers reported the similar finding for the optimum biosorption temperatures. ${ }^{23,8,20)}$ The temperature of the adsorption medium could be important for energy dependent mechanisms in metal biosorption by microbial cells. Generally, adsorption is an exothermic process, although some examples of endothermic adsorption have been reported. ${ }^{8)}$

\subsubsection{Effect of Contact Time on the Biosorption of $\mathrm{Cr}$ (VI)}

The effect of contact time on the uptake of $\mathrm{Cr}$ (VI) $(100 \mathrm{mg} / \mathrm{L})$ by dried biomass and live-heat-inactivated Oscillatoria sp. immobilized alginate beads was investigated in different durations $(0,5,10,15,30,60,90,120 \mathrm{~min})$. The $\mathrm{Cr}$ (VI) adsorption rate was high at the beginning of adsorption and the saturation levels were completely reached at about $60 \mathrm{~min}$ for $\mathrm{Cr}$ (VI) ions (Fig. 3). After this equilibrium period, the amount of adsorbed $\mathrm{Cr}$ (VI) ions on 


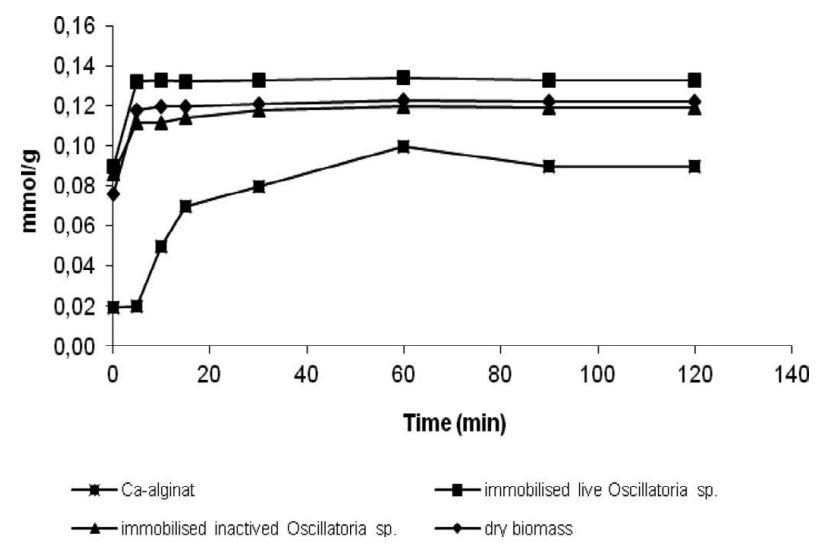

Fig. 3. Effect of contact time on the uptake of $\mathrm{Cr}$ (VI).

the biosorbents did not significantly change with time. This trend in binding of $\mathrm{Cr}$ (VI) ions suggests that the binding may be through interactions with functional groups located on the surface of the biosorbents.

Cr (VI) biosorption of dry biomass, immobilized live and heat-inactivated Oscillatoria sp. could be divided into two stages; a fast initial rate followed by a much slower biosorption rate. Similar results have been reported by other researchers. Arica et al. ${ }^{6}$ divided the Cr (VI) biosorption of free and immobilized fungus into two stages; a first stage with a high rate and a much slower second one lasting approximately $150 \mathrm{~min}$. To reach biosorption equilibrium. Chojnacka et al. ${ }^{11)}$ attributed the fast initial metal biosorption rate to the surface binding by natural particles, and the following slower sorption to the interior penetration.

\subsubsection{Effect of Initial Concentration of $\mathrm{Cr}$ (VI) on Bio- sorption}

The effect of the initial concentration of chromium (VI) ion on the uptake of Cr (VI) by dry biomass, alginate beads and both immobilized live and heat inactivated Oscillatoria sp. was also studied in the range of $25-200 \mathrm{mg} / \mathrm{L}$ (Fig. 4). The results showed that the retained $\mathrm{Cr}$ (VI) increased by increasing the concentration of $\mathrm{Cr}$ (VI) in solution. When the initial $\mathrm{Cr}$ (VI) concentration was increased from 25 to $200 \mathrm{mg} / \mathrm{L}$, the retained chromium increased approximately from 2.7 to $20.82 \mathrm{mg} / \mathrm{g}$ for the dry biomass, live and heat inactivated Oscillatoria sp., respectively. The results showed that immobilized inactivated cells and dry biomass had less available adsorptive sites for biosorption of metal ions than that of the immobilized live form (13.83, 15.81 and $20.82 \mathrm{mg} / \mathrm{g}$ ). Arıca and Bayramoğlu ${ }^{24)}$ reported that the amount of biosorbed $\mathrm{Cr}$ (VI) ions on the CMC (carboxymethylcellulose), free and immobilized fungus preparation were $5.1,18.9$ and $32.3 \mathrm{mg} / \mathrm{g}$ dry adsorbents.

\subsubsection{Effect of Amount of Adsorbent (Bead and Dry Weight)}

The retention of $\mathrm{Cr}$ (VI) ions was examined in relation to the amount of adsorbent. For this purpose, the amounts of adsorbent were tested in a range of $0.02-0.1 \mathrm{~g}$ and $20-40$ bead. It was found that the retention of $\mathrm{Cr}$ (VI) ions increased with increasing the amount of the adsorbent up to $0.04 \mathrm{~g}$ and 30 bead. Above these amounts, it practically did not change.

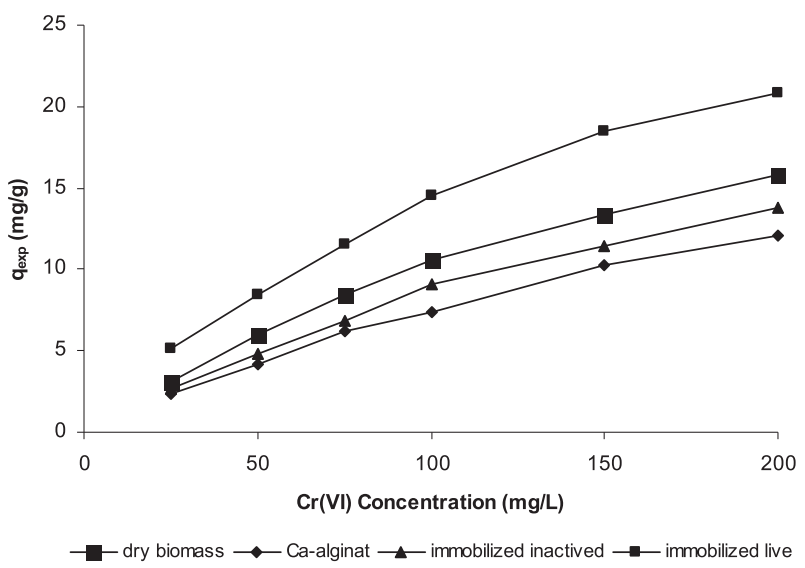

Fig. 4. Effect of initial $\mathrm{Cr}(\mathrm{VI})$ concentration (temperature: $25^{\circ} \mathrm{C}$, $\mathrm{pH}$ : 6.0, agitation rate: $100 \mathrm{rpm}$, contact time: $60 \mathrm{~min}$ ).

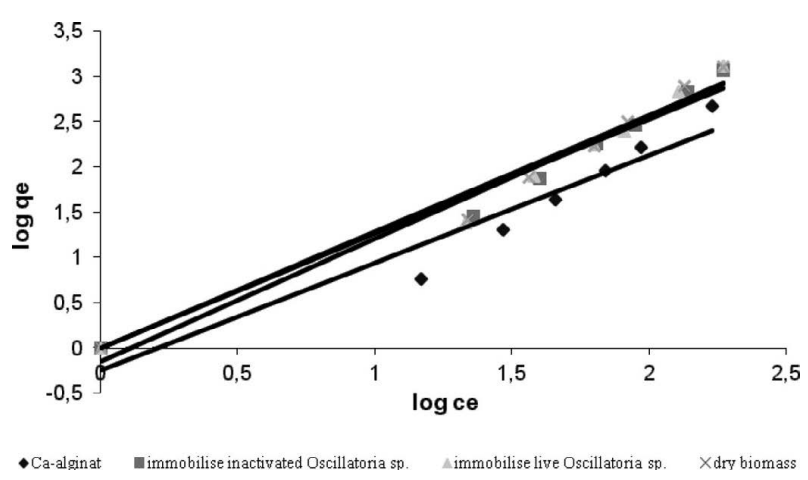

Fig. 5. The linearized Freundlich adsorption isotherms of $\mathrm{Cr}$ (VI).

\subsection{Langmuir and Freundlich Adsorption Isotherms}

An adsorption isotherm is characterized by certain constants the values of which express the surface properties and affinity of the sorbent. Out of several isotherm equations the two most commonly used, the Langmuir and Freundlich adsorption isotherms have been investigated in this study. In this study, both models were applied to describe the relationship between the adsorbed amount of chromium and its equilibrium concentration in solution.

During biosorption, a rapid equilibrium is established between adsorbed metal ions on biosorbent (q) and unadsorbed metal ions in solution $(\mathrm{C})$. The Langmuir equation suggests the monolayer sorption on to a surface containing finite number of identical sites. Its linearized form is represented by the following equation. ${ }^{25}$ )

$$
\frac{\mathrm{C}}{\mathrm{q}}=\frac{1}{\mathrm{Q}_{\max } \mathrm{b}}+\frac{\mathrm{C}}{\mathrm{Q}_{\max }}
$$

where, $\mathrm{C}$ is the concentration of chromium in solution $(\mathrm{mg} / \mathrm{L})$ at equilibrium, $\mathrm{q}$ is the amount of adsorbed chromium per gram of adsorbent at equilibrium ( $\mathrm{mg} / \mathrm{g}), \mathrm{b}$ is the Langmiur constant related to the energy of adsorption $(1 / \mathrm{mg})$ and $\mathrm{Q}_{\max }$ is the adsorption capacity of the adsorbent $(\mathrm{mg} / \mathrm{g})$. Based on the linearized form of the adsorption isotherm derived from plots of $\mathrm{C} / \mathrm{q}$ versus $\mathrm{C}$, the constant $\mathrm{Q}_{\max }$ values were calculated from the slope of graph. ${ }^{25}$ The empirical Freundlich equation based on sorption on a heterogeneous surface is given by the following equation:

$$
\mathrm{q}=\mathrm{K}_{\mathrm{F}} \cdot \mathrm{C}^{1 / \mathrm{n}}
$$


Table 1. Langmuir and Freundlich parameters for the adsorption isotherms of adsorbent for $\mathrm{Cr}$ (VI) ion.

\begin{tabular}{lcccccc}
\hline & \multicolumn{3}{c}{ Langmuir } & \multicolumn{3}{c}{ Freundlich } \\
\cline { 2 - 7 } & $\mathrm{Q}_{\mathrm{m}}$ & $\mathrm{b}$ & $\mathrm{R}^{2}$ & $\mathrm{~K}_{\mathrm{F}}$ & $\mathrm{n}$ & $\mathrm{R}^{2}$ \\
\hline Dried biomass & 36.50 & $3.90 \times 10^{-3}$ & 0.984 & 0.27 & 1.27 & 0.980 \\
Ca-Alginate & 31.25 & $3.17 \times 10^{-3}$ & 0.987 & 0.18 & 1.24 & 0.990 \\
Oscillatoria sp. (live) & 39.06 & $5.80 \times 10^{-3}$ & 0.988 & 0.57 & 1.45 & 0.990 \\
Oscillatoria sp. (inactivated) & 34.25 & $3.40 \times 10^{-3}$ & 0.978 & 0.21 & 1.26 & 0.990
\end{tabular}

$\mathrm{Q}_{\mathrm{m}}(\mathrm{mg} / \mathrm{g})$

$\mathrm{b}$ is Langmuir adsorption constant $(1 / \mathrm{mg})$

$\mathrm{R}^{2}$ is correlation coefficient

$$
\log \mathrm{q}=\log \mathrm{K}_{\mathrm{F}}+(1 / \mathrm{n} \log \mathrm{C})
$$

where, $K_{F}$ and $n$ are the Freundlich constants. $K_{F}$ and $n$ are indicators of adsorption capacity and adsorption intensity, respectively. The Freundlich isotherm has generally been considered an empirical relationship and has been widely used to fit the experimental data (Fig. 3). The Freundlich constants $\mathrm{K}_{\mathrm{F}}$ and $\mathrm{n}$ were obtained from the linearized logarithmic plot of Eq. 2. ${ }^{26)}$ The plots of linearized Langmuir and Freundlich adsorption isotherms were obtained from the conducted equilibrium biosorption experiments at $25^{\circ} \mathrm{C}$ and $\mathrm{pH}$ 6. The Langmuir and Freundlich adsorption constants evaluated from these isotherms are also given in Table 1. The correlation coefficients of the isotherms are found to be high enough for all of the sorbate-sorbent systems.

Freundlich parameters indicated a serious increase in $\mathrm{Cr}$ (VI) uptake by the immobilization of Oscillatoria sp. in Caalginate beads. The maximum biosorption capacities of dried biomass and immobilized live Oscillatoria sp. were observed to be higher than the maximum adsorption capacity of the plain alginate beads and immobilized heat inactivated, respectively. Also, the maximum biosorption capacity of the immobilized live Oscillatoria sp. was found to be higher than the adsorption capacity of the dried biomass and immobilized heat inactivated counterpart. Although, the obtained low $\mathrm{b}$ values implied a weak bonding of $\mathrm{Cr}$ (VI) to the biosorbents, the magnitude of Freundlich constants, $\mathrm{K}_{\mathrm{f}}$ and $\mathrm{n}$, showed easy uptake of $\mathrm{Cr}$ (VI) ions from the aqueous medium.

\subsection{Reusability of Biosorbent}

Desorption of the adsorbed $\mathrm{Cr}$ (VI) ions from the biosorbent was studied in a batch system. In order to show the reusability of the biosorbent the adsorption-desorption cycle of $\mathrm{Cr}$ (VI) ions was repeated three times using the same preparations. The adsorption capacities for all the biosorbents did not noticeably change during the repeated (three times) adsorption-desorption operations. Also, the desorption efficiency of the biosorbed metal ions from immobilized live Oscillatoria sp. was determined as $98 \%$. But, it is known that the adsorption capacity of the algal biomass for $\mathrm{Cr}$ (VI) ions decreased down to $2 \%$ during the repeated adsorption-desorption operations. A possible cause of reduction in the biosorption capacity of the algal cells could be attributed to the adverse effect of the desorbing agent on the binding sites of the algal cell wall components.
Table 2. A comparison of adsorption capacities of various biosorbents for $\mathrm{Cr}(\mathrm{VI})$.

\begin{tabular}{|c|c|c|}
\hline Type of biosorbents & $\begin{array}{c}\mathrm{Cr}(\mathrm{VI}) \text { uptake } \\
\mathrm{Q}_{\mathrm{m}}(\mathrm{mg} \mathrm{Cr} / \mathrm{g} \\
\text { biomass })\end{array}$ & References \\
\hline L. sajor-caju (free- inactive) & 18.9 & {$[24]$} \\
\hline L. sajor-caju (immobilized with CMC-active) & 32.2 & {$[24]$} \\
\hline Dunaliella sp. (active) & 58.3 & {$[27]$} \\
\hline Dunaliella sp. (active) & 45.5 & {$[27]$} \\
\hline Chlorella vulgaris (inactive) & 23.6 & {$[28]$} \\
\hline Clodophora crispate (inactive) & 30.4 & [29] \\
\hline Scenedesmus obliquus (inactive) & 15.6 & {$[30]$} \\
\hline Synechocystis sp. (inactive) & 19.2 & {$[30]$} \\
\hline Rhizopus nigricans (free-inactive) & 49.8 & {$[31]$} \\
\hline $\begin{array}{l}\text { Rhizopus nigricans (immobilized-Ca- alginate, } \\
\text { inactive) }\end{array}$ & 34.7 & {$[31]$} \\
\hline Oscillatoria sp. (free-inactive) & 36.4 & This study \\
\hline $\begin{array}{l}\text { Oscillatoria sp. (immobilized with } \\
\text { Ca-alginate, inactive) }\end{array}$ & 34.2 & This study \\
\hline $\begin{array}{l}\text { Oscillatoria sp. (immobilized with } \\
\text { Ca-alginate, active) }\end{array}$ & 39.1 & This study \\
\hline
\end{tabular}

\subsection{Evaluation of Immobilized and Free Biosorbents}

In order to demonstrate the validity of proposed method, adsorption potential of immobilized live Oscillatoria sp. could be compared with other adsorbents used for this purpose. Table 2 compares the maximum adsorption capacities obtained in the present work with those reported in other studies. Table 2 shows that immobilized live Oscillatoria sp. has good enough adsorption capacity when compared with other biosorbents. The differences of adsorption capacities are ascribed to the properties of different adsorbents such as structure, functional groups and surface area.

\section{Conclusion}

In this study, the $\mathrm{Cr}$ (VI) adsorption properties of dry biomass, immobilized live and heat-inactivated Oscillatoria sp. were studied. The results showed that the immobilized live Oscillatoria sp. had a higher biosorption capacity than the dry biomass and heat-inactivated Oscillatoria sp. Tien ${ }^{32}$ ) reported that Oscillatoria limnetica was a thin layer of diffuse mucilage, high surface area/dry weight ratio and the structure of mucilage may be able to explain the binding mechanisms. Therefore, there are no reports on biosorption of metals by Oscillatoria sp., which grows readily and forms a good mass that can be conveniently used for biosorption studies. Rapid growth and early harvestable biomass of this cyanobacterium ensures ready availability of this system as a biosorbent, which is both cost-effective and non toxic. Use of algal biomass in powder form is more in practice for biosorption purposes. However, separation of the algal powder from the wastewater after use becomes a major practical problem. Immobilization of the algae, on the other hand, not only avoids biomass-liquid separation, but also allows higher local cell density and retention of biomass within a definite working system that can be reused.

Consequently, the immobilized live Oscillatoria sp. may 
be suitable for development of efficient biosorbent for the removal of chromium from wastewater. The Freundlich and Langmuir adsorption models were used for the mathematical description of the biosorption of $\mathrm{Cr}$ (VI). The biosorption was well described by Freundlich adsorption isotherms. The good fit of experimental data to the Freundlich sorption model was indicated the presence of the heterogeneous binding sites on algal surfaces.

\section{Acknowledgements}

The authors are grateful to Gazi University Research Fund for support of this work.

\section{REFERENCES}

1) B. Kiran, A. Kaushik and C. P. Kaushik: J. Hazard. Mater., 141 (2006), 662 .

2) Y. Sağ, Ü. Açıkel, Z. Aksu and T. Kutsal: Process Biochem., 33 (1998), 273.

3) H. Bağ, A. R. Türker, M. Lale and A. Tunçeli: Talanta, 51 (2000), 895.

4) G. Özdemir, N. Ceyhan, T. Öztürk, F. Akirmak and T. Cosşar: Chem. Eng. J., 102 (2004), 249.

5) K. Mohanty, M. Jha, B. C. Meikap and M. N. Biswas: Chem. Eng. J., 117 (2006), 71.

6) M. Y. Arıca, G. Bayramoğlu, M. Yılmaz, S. Bektaş and Ö. Genç: J. Hazard. Mater., B109 (2004), 191.

7) A. Ergene, S. Tan, H. Katırcığlu and Z. Öktem: Fresen. Environ. Bull., 15 (2006), 283.

8) İ. Tüzün, G. Bayramoğlu, E. Yalçın, G. Başaran, G. Çelik and Y. Arıca: J. Environ. Manage., 77 (2005), 85.

9) Y. Kaçar, C.. Arpa, S. Tan, A. Denizli, Ö. Genç and M. Y. Arıca: Process Biochem., 37 (2002), 601.

10) J. B. Yang and B. Volesky: Environ. Sci. Technol., 33 (1999), 751.
11) K. Chojnacka, A. Chojnacki and H. Gorecka: Chemosphere, 59 (2005), 75.

12) R. S. Prakasham, J. S. Merrie, R. Shella, N. Saswath and S. V. Ramakrishna: Environ. Pollut., 104 (1999), 421.

13) R. Rippka: Methods in Enzymology, Academic Press, New York, 167 (1988), 3

14) D. R. Bone, R. W. Castenholz and G. M. Garrity: Bergey's Manual of Systematic Bacteriology, Vol. 1, Academic Press, New York, (2001), 473.

15) Y. C. Chen: Aquaculture, 195 (2001), 71.

16) R. İnam and Ç. Toprak: Fresen. Environ. Bull., 14 (2005), 489.

17) C. S. F. Nordi, A. A. H. Vieira and O. R. Nascimento: Process Biochem., 40 (2005), 2215.

18) M. Kelly: Mining and the Freshwater Environment, Elsevier Applied Science, Netherlands, Amsterdam, (1988), 12.

19) R. H. Crist, J. R. Martin, D. Carr, J. R. Watson and H. J. Clarke: Environ. Sci. Technol., 28 (1994), 1859.

20) X. Han, Y. S. Wong, M. H. Wong and N. F. Y. Tam: J. Hazard. Mater., 146 (2006), 65.

21) S. Congeevaram, S. Dhanarani, J. Park, M. Dexilin and K. Thamaraiselvi: J. Hazard. Mater., 146 (2007), 270.

22) A. Baran, E. Bıçak, Ş. H. Baysal and S. Önal: Bioresource Technol., 98 (2006), 661.

23) T. Nakipoğlu and H. C. Sevindir: Süleyman Demirel Üniversitesi, Fen Bilimleri Enstitüsü Dergisi, 10 (2006), 284.

24) M. Y. Arıca and G. Bayramoğlu: Colloids Surfaces A: Physicochem. Eng. Aspects, 253 (2005), 203.

25) A. W. Adamson: Physical Chemistry of Surface, 5th ed., Wiley, New York, (1990), 1.

26) F. M. M. Morell and J. G. Hering: Principles and Applications of Aquatic Chemistry, Wiley, NewYork, (1993), 509.

27) G. Dönmez and Z. Aksu: Process Biochem., 38 (2002), 751.

$28)$ Z. Aksu and T. Kutsal: Environ. Technol., 11 (1990), 979.

29) Z. Aksu, D. Özer, H. I. Ekiz, T. Kutsal and A. Çağlar: Environ. Technol., 17 (1996), 215.

30) G. Ç. Dönmez, Z. Aksu, A. Öztürk and T. Kutsal: Process Biochem., 34 (1999), 885.

31) R. S. Bai and T. E. Abraham: Bioresouce Technol., 87 (2003), 17.

32) C. J. Tien: Process Biochem., 38 (2002), 605. 